\title{
EFFECT OF HILL SPACING AND NITROGEN FERTILIZATION LEVEL ON THE NEW PROMISING EGYPTIAN COTTON HYBRID GIZA $90 \times$ AUSTRALIAN
}

\author{
Abdel-Malak, K.K.; M. A. Emara and S.A. Hamoda \\ Agronomy Research Section, Cotton Research Institute, Agricultural Research Center, Giza, Egypt.
}

\begin{abstract}
Two field experiments were carried out in Mallawy Agricultural Research Station, Minia Governorate, Middle Egypt, during 2010 and 2011 seasons to find out the effect off hill spacing and nitrogen fertilization level on the new promising Egyptian cotton hybrid Giza 90 x Australian (Gossypium barbadense L.,). The experimental design was a split plot block with four replications. The main plots were devoted to four hill spacings $(20,25,30$ and $35 \mathrm{~cm})$ and the sub plots for four nitrogen fertilization levels $(30$, 45,60 and $75 \mathrm{~kg} \mathrm{~N} / \mathrm{fed}$.). The results indicated that hill spacing and nitrogen fertilization levels had significant effects on no. of sympodia/plant, earliness \%, no. of open bolls/plant, boll weight and seed cotton yield/fed while, but not on plant height, first sympodial position, seed index and lint \%. Increasing hill spacing to $35 \mathrm{~cm}$ between hills significantly increased no of sympodia/plant, no. of open bolls/plant, boll weight, seed cotton yield/fed, but decreased earliness $\%$. Increasing $\mathrm{N}$ levels from 30 to $75 \mathrm{~kg} \mathrm{~N} /$ fed exhibited a significant increase in each of no. of sympodia/plants, no. of harvested plants/fed, earliness \%, no. of open bolls/plant, boll weight and seed cotton yield/fed. The interaction between hill spacing and nitrogen level exerted significant effects on no. of sympodia/plant, earliness \% and boll weight in both seasons, no. of open bolls/plant in the first season and seed cotton yield/fed in the second season. The combination between $35 \mathrm{~cm}$ hill spacing and 60 or $75 \mathrm{Kg} \mathrm{N} / \mathrm{fed}$. gave the highest averages of no. of sympodia/plant, boll weight, no. of open bolls/plant and seed cotton yield/fed. The effect of hill spacing and nitrogen fertilization level and their interactions did not exhibit any significant effect on all fiber properties under study. It could be concluded that $35 \mathrm{~cm}$ hill spacing and $60 \mathrm{Kg} \mathrm{N} / \mathrm{fed}$. could be recommended production of this new cotton hybrid Giza 90 x Australian under Middle Egypt location.
\end{abstract}

Key words: Cotton, Hybrid, Hill spacing, Nitrogen fertilization, Growth, Productivity and Fiber.

\section{INTRODUCTION}

Plant population is one of the most important management practices which require attention as far as yield is concerned in cotton production. Plant population in cotton could be adjusted by manipulating inter and intra-row hill spacing as well as no. of plants/hill. The proper plant density/fed. results into higher yield, earlier maturity and reduces cost of insect and weed control. The proper plant spacing is one of the management practices that affect canopy light interception, maturity and dry matter of the cotton plant.

(Eweida et al, 1981) found that the no. of nodes and fruiting branches/plant were significantly affected by hill spacing where the no. of

Fayoum J. Agric. Res. \& Dev., Vol. 26, No.1, January, 2012 
Abdel-Malak, K.K.; et al.

open bolls/plant was increased with wider spacing while boll weight, fibre length, strength and fineness were not affected by plant density. (Abd ElMalik and El-Shahawy, 1999) found that low density stands increased plant height, no. of fruiting branchs, earliness \%, no. of open bolls/ plant, boll weight and seed cotton yield/fed.. (El-Sayed and El-Menshawi, 2005) found that wider hill spacing increased earliness \%, no. of open bolls/plant, boll weight and seed cotton yield. (Dong $\boldsymbol{e t}$ al, 2005) found that seed cotton yield and lint percentage did not significantly differ among three plant densities. (Obasi and Msaakpa, 2005) indicated that wider hill spacing increased no. of sympodia, open bolls, boll weight and seed cotton yield while, it decreased plant height and earliness \%. (Hamed, 2006) indicated that increasing plant population i.e. $64.600,51.700$ and 43.100 plants/fed. produced the best averages of the first fruiting branch node, no. of plants/fed and seed cotton yield/fed while, decreasing population density led to a significant increase in no. of fruiting branches/plant, no. of open bolls/plant, boll weight and seed cotton yield/plant. (El-Shahawy and Hamoda, 2011) found that increasing hill spacing from 20 to $30 \mathrm{~cm}$ significantly increased no. of sympodia/plant, no. of open bolls/plant, boll weight and seed cotton yield /fed. while, plant height, first sympodial position and lint \% decreased.

Nitrogen is one of the most important nutrient elements in cotton production. Adequate levels of nitrogen fertilization may produce a higher yield and quality, but higher levels may result in excessive vegetative growth with a lower yield and quality. In this respect, several studies were done to evaluate the response of cotton plants to different nitrogen levels.

(El-Ganaini et al, 2005) found that number of open bolls/plant, boll weight and seed cotton yield/fed., were increased with increasing levels of nitrogen. (Khan et al, 2005) found that seed cotton yield, number of bolls per plant and boll weight increased with increasing rates of N. (Hamed, 2006) indicated that the plant height, no. of fruiting branches/plant, no. of open bolls/plant and seed cotton yield/plant were significantly increased by increasing nitrogen levels up to $(45,60$ and 75$) \mathrm{Kg}$ N/fed.. (Sawan et al, 2006) showed that no. of open bolls/plant, boll weight, seed index and seed cotton yield/plant were increased with the higher $\mathrm{N}$ rate. Nitrogen effects on fibre properties were small and inconsistent. (Srinivasulu $\boldsymbol{e t}$ al, 2006) found that the seed cotton yield obtained with the $120 \mathrm{~kg}$ N/ha rate was significantly higher than the seed cotton yield observed with the $90 \mathrm{~kg} \mathrm{~N} / \mathrm{ha}$ rate. Nitrogen level did not affect the quality of the fibre. (Ahmed and Kassem, 2008) found that increasing nitrogen level to $90 \mathrm{~kg} \mathrm{~N} / \mathrm{fed}$ significantly increased plant height and no. of fruiting branches/plant but, it failed to exert any significant effects on yield or yield components. (Ibrahim, 2008) found that plant height, no. of fruiting branches/plant, no. of open bolls/plant, boll weight, no. of plants/fed., seed index, lint \%, seed cotton yield/plant, seed cotton yield/fed., fiber length, fiber strength, micronaire values and fiber elongation were significantly increased by increased NPK fertilizations levels at $80 \mathrm{~kg} \mathrm{~N}+30$ $\mathrm{kg} \mathrm{P}_{2} \mathrm{O}_{5}+48 \mathrm{~kg} \mathrm{~K} 2 \mathrm{O} / \mathrm{fed}$. (Hamoda, 2010) found that the increase of $\mathrm{N}$ level to $60 \mathrm{~kg} \mathrm{~N} / \mathrm{fed}$. exhibited a significant increase in each of plant height, no. of fruiting branches/plant, no. of open bolls/plant, boll weight, seed index, seed cotton yield/fed. and gave the best fiber quality. (El-Shahawy and Hamoda, 2011) found that plant height, no. of sympodia/plant, first sympodial position, no. of open bolls /plant, boll weight, seed index and seed cotton yield/fed.

Fayoum J. Agric. Res. \& Dev., Vol. 26, No.1, January, 2012 
were increased by increasing nitrogen levels but did not exhibit any significant effect on all fiber properties under study.

The main purpose of this study was to investigate the effect of hill spacing and nitrogen fertilization level on growth and productivity of the new promising cotton hybrid Giza 90 x Australian under Middle Egypt conditions.

\section{MATERIALS AND METHODS}

Two field experiments were carried out in Mallawy Agricultural Research Station, Minia Governorate, Middle Egypt, during 2010 and 2011 seasons to study the effect of hill spacing and nitrogen fertilization level on growth, earliness, yield and fiber quality of the new promising cotton hybrid Giza 90 x Australian (Gossypium barbadense, L.). Characters this cotton hybrid are shown in Table (1).

Table 1. Main characters the new promising cotton hybrid Giza $90 \times$ Australian.

\begin{tabular}{|l|l|}
\hline Hybrid name & New promising cotton hybrid Giza 90 x Australian. \\
\hline Species & Barbadense. \\
\hline Pategory & Long staple \\
\hline Characteristics & $\begin{array}{l}\text { Long staple characterized by high yielding, early maturity, high lint \%, } \\
\text { resistance to fuzariam and tolerance to relatively high temperature } \\
\text { (Middle Egypt). }\end{array}$ \\
\hline $\begin{array}{l}\text { Botanical } \\
\text { distinguishing } \\
\text { characters }\end{array}$ & $\begin{array}{l}\text { The stem has a medium length also has pale purple color. The leaf is of } \\
\text { first fruiting branch ranged from 6-7. The flower petal has tubular shape. } \\
\text { The boll is of conical shape: non-tapering shape (Tity). Seed is of } \\
\text { medium size and semi racked to 1/4 from fuzz covers. Fuzz color is gray. } \\
\text { Lint color is creamy }\end{array}$ \\
\hline Hybrid bred by & Breeding Res. Section, Cotton Res., Agric. Res. Center, Giza, Egypt. \\
\hline
\end{tabular}

The experimental design was a split plot block with four replications. Main plots were devoted to four hill spacings (20, 25, 30 and $35 \mathrm{~cm})$ and the sub plots were devoted for four nitrogen fertilization levels $(30,45,60$ and $75 \mathrm{~kg} \mathrm{~N} / \mathrm{fed}$.). The experimental unit included 8 ridges $(5 \mathrm{~m}$ long and $65 \mathrm{~cm}$ apart) occupying an area of $26 \mathrm{~m}^{2}$. Cotton seeds were planted on 25 March in the two seasons. Hills were and seedlings were thinned at 2 plants/hill after 25 days from planting. Phosphorus fertilizer as ordinary superphosphate $(15.5 \%$ $\mathrm{P}_{2} \mathrm{O}_{5}$ ) at the level of $22.5 \mathrm{~kg} \mathrm{P}_{2} \mathrm{O}_{5} / \mathrm{fed}$. was incorporated during seed bed preparation. Nitrogen fertilization was applied in the form of ammonium nitrate $(33.5 \% \mathrm{~N})$ at the tested level in two equal doses i.e. immediately before the first and the second irrigations (29 and 45 days after planting). Potassium fertilization was applied in the form of potassium sulfate $\left(48 \% \mathrm{~K}_{2} \mathrm{O}\right)$ at the level of $24 \mathrm{~kg} \mathrm{~K} 2 \mathrm{O} / \mathrm{fed}$. in a single dose before the second irrigation. Standard agricultural practices were followed throughout the growing seasons. Soil analysis of the experimental site in the two growing seasons was shown in Table (2).

Table 2. Soil analysis of the experimental sites in the two seasons.

\begin{tabular}{|c|c|c|c|c|c|c|c|c|}
\hline \multirow{3}{*}{ Seasons } & \multicolumn{8}{|c|}{ Soil properties } \\
\hline & \multirow{2}{*}{$\begin{array}{c}\text { Soil } \\
\text { Texture }\end{array}$} & \multirow{2}{*}{$\mathbf{p H}$} & \multirow{2}{*}{$\begin{array}{c}\text { Organic } \\
\text { matter } \\
(\%)\end{array}$} & \multirow{2}{*}{$\begin{array}{c}\text { EC m } \\
\text { mhos/cm }\end{array}$} & \multirow{2}{*}{$\mathrm{Ca} \mathrm{CO}_{3} \%$} & \multicolumn{3}{|c|}{ Available element (ppm) } \\
\hline & & & & & & $\mathbf{N}$ & $\mathbf{P}$ & $\mathbf{K}$ \\
\hline 2010 & Clay loam & 7.9 & 1.16 & 0.36 & 3.22 & 23 & 9.5 & 333 \\
\hline 2011 & Clay loam & 8.1 & 1.09 & 0.35 & 2.30 & 22 & 13 & 288 \\
\hline
\end{tabular}

Fayoum J. Agric. Res. \& Dev., Vol. 26, No.1, January, 2012 
Plants of five representative hills were taken at random from each plot to study the following traits: plant height $(\mathrm{cm})$, no. of sympodia/plant, first sympodial position, boll weight (gm), number of open bolls/plant, lint \% and seed index (gm). The seed cotton yield (ken./fed.) was estimated as the weight of seed cotton yield (kilogram) picked twice from the six central rows of each plot, then converted to yield per fedden in kentar $($ Kentar $=157.5 \mathrm{~kg}$.). Earliness index was determined as percent of seed cotton yield at first pick to total seed cotton yield/plot. Also, number of plants/fed. at harvest (1000 plants/fed.) was determined. All fiber tests were performed at the laboratories of the Cotton Technology Research Division, Cotton Research Institute, Agricultural Research Center, Giza, Egypt, at a constant relative humidity $65 \% \pm 2$ and temperature $21^{\circ} \mathrm{C} \pm 2$. Fiber properties (upper half mean length (UHM) in mm, uniformity index, fiber strength in $\mathrm{g} / \mathrm{tex}$., fiber elongation \% and micronaire reading were measured using High Volume Instrument (HVI) fiber test system according to (A.S.T.M. 1986). Data were subjected to statistical analysis as proposed by (Gomez and Gomez, 1984) and means were compared by LSD at 5\% level of probability.

\section{RESULTS AND DISCUSSION}

The effect of hill spacing, nitrogen level and their interactions on growth, earliness, yield and its components and fiber properties for the new promising cotton hybrid Giza 90 x Australian are shown in Tables (3) to (8).

\section{1- Effect of hill spacing:}

Data in Table (3) showed that no. of sympodia/plant and earliness \% were significantly affected by hill spacing which did not exhibit any significant effect on plant height at harvest and first sympodial position in both seasons. Wider spacing of $35 \mathrm{~cm}$ gave the highest values of no of sympodia/plant and earliness traits compared with the other hill spacings under study. Similar results were obtained by (Abd El-Malik and El-Shahawy, 1999).

Table 3. Effect of hill spacing and nitrogen fertilization levels on growth and earliness traits of the new promising cotton hybrid Giza $90 \mathrm{x}$ Australian during 2010 and 2011 seasons.

\begin{tabular}{|c|c|c|c|c|c|c|c|c|c|}
\hline \multirow{3}{*}{\multicolumn{2}{|c|}{ Treatments }} & \multicolumn{4}{|c|}{ Growth parameters } & \multicolumn{4}{|c|}{ Earliness traits } \\
\hline & & \multicolumn{2}{|c|}{$\begin{array}{c}\text { Plant height } \\
\text { at harvest }(\mathrm{cm})\end{array}$} & \multicolumn{2}{|c|}{$\begin{array}{c}\text { No. of } \\
\text { sympodia/plant }\end{array}$} & \multicolumn{2}{|c|}{$\begin{array}{l}\text { First sympodial } \\
\text { position }\end{array}$} & \multicolumn{2}{|c|}{$\begin{array}{c}\text { Earliness } \\
(\%)\end{array}$} \\
\hline & & 2010 & 2011 & 2010 & 2011 & 2010 & 2011 & 2010 & 2011 \\
\hline \multirow{4}{*}{$\begin{array}{c}\text { Hill } \\
\text { spacing }\end{array}$} & $20 \mathrm{~cm} / \mathrm{hills}$ & 109.83 & 124.00 & 12.33 & 12.44 & 8.2 & 7.0 & 74.86 & 73.61 \\
\hline & $25 \mathrm{~cm} / \mathrm{hills}$ & 112.21 & 123.88 & 13.30 & 12.90 & 8.1 & 7.0 & 75.64 & 74.55 \\
\hline & $30 \mathrm{~cm} / \mathrm{hills}$ & 109.83 & 117.96 & 13.60 & 14.62 & 8.0 & 7.1 & 77.53 & 74.31 \\
\hline & $35 \mathrm{~cm} / \mathrm{hills}$ & 114.67 & 123.63 & 13.93 & 15.50 & 7.9 & 7.1 & 78.08 & 74.80 \\
\hline \multicolumn{2}{|c|}{ LSD } & N.S & N.S & 0.19 & 0.37 & N.S & N.S & 0.73 & 0.48 \\
\hline \multirow{4}{*}{$\begin{array}{c}N \\
\text { fertilization } \\
\text { levels }\end{array}$} & $30 \mathrm{~kg}$ N/fed. & 109.04 & 116.79 & 12.16 & 13.00 & 8.0 & 7.1 & 77.06 & 76.71 \\
\hline & $45 \mathrm{~kg}$ N/fed. & 110.50 & 121.88 & 13.18 & 13.47 & 8.0 & 7.1 & 77.08 & 75.11 \\
\hline & $60 \mathrm{~kg} \mathrm{~N} / \mathrm{fed}$. & 112.75 & 124.58 & 13.83 & 14.24 & 8.0 & 7.1 & 76.67 & 73.67 \\
\hline & $75 \mathrm{~kg}$ N/fed. & 114.25 & 126.21 & 14.00 & 14.75 & 8.1 & 7.1 & 75.29 & 71.78 \\
\hline \multicolumn{2}{|c|}{ LSD } & N.S & N.S & 0.17 & 0.24 & N.S & N.S & 0.53 & 0.34 \\
\hline
\end{tabular}

Fayoum J. Agric. Res. \& Dev., Vol. 26, No.1, January, 2012 
Results presented in Table (5) indicated that hill spacings significantly affected on no. of open bolls/plant, boll weight and no. of plants/fed. in both seasons and seed cotton yield/fed. in the second season only. Increasing hill spacing to $35 \mathrm{~cm}$ significantly increased no. of open bolls/plant, boll weight, seed cotton yield/fed. Hill spacing did not exhibit any significant effect on seed index and lint $\%$. The no. of harvested plants/fed. was significantly increased as a result of decreasing distance between hills in both seasons. With using the suitable wide hill spacing might have had increased light intensity within the plant canopy which, increased seed cotton yield, due to a higher production of bolls per plant and increase in boll weight. These results are in harmony with those obtained by (ElSayed and El-Menshawi, 2005).

Data in Table (7) showed that hill spacing treatments did not exhibit any significant effect on all fiber properties under study in both seasons. Similar results were obtained by (Eweida et al, 1981).

2- Effect of nitrogen fertilization level:

Data in Table (3) showed that nitrogen fertilization level had a significant effect on no of sympodia/plant and earliness \% but did not exhibit any significant effect on plant height at harvest and first sympodial position in both seasons. Increasing N level from 30 to $75 \mathrm{~kg} \mathrm{~N} /$ fed exhibited a significant increase in no of sympodia/plant where cotton plants under $75 \mathrm{~kg} \mathrm{~N}$ had more no. of fruiting branches than those received 30,45 or $60 \mathrm{Kg} \mathrm{N} / \mathrm{fed}$. without any significant differences with the level of $60 \mathrm{Kg} \mathrm{N} / f$ ed. These results may be due to the well known roles of $\mathrm{N}$ in building up the plant tissues and stimulating its growth. It is well established that cotton plant, owing to its indeterminate growth habit, responds favorably to increasing $\mathrm{N}$ rate where its growth is linearly correlated with $\mathrm{N}$ supply (Silvertooth $\boldsymbol{e t} \boldsymbol{a l}$, 2007). Increasing N level from 30 to $75 \mathrm{~kg} \mathrm{~N} / \mathrm{fed}$. decreased earliness \%. Both levels of $60 \mathrm{~kg} \mathrm{~N} / f$ d. and $75 \mathrm{~kg} \mathrm{~N} / \mathrm{fed}$ gave the best values of no. of sympodia/plant without any differences between them. Similar results were obtained by (Hamed, 2006) and (Hamoda, 2010).

It is clear from Tables (5) that increasing $\mathrm{N}$ fertilization level from 30 to 75 $\mathrm{kg} \mathrm{N} /$ fed exhibited a significant increase in no. of open bolls/plant, boll weight and seed cotton yield/fed in both seasons, while lint \%, no. of harvest plants/fed. and seed index were insignificantly affected by $\mathrm{N}$ levels. In this respect (El-Shahawy and Hamoda, 2011) found that no. of open bolls/plant, boll weight, seed index and seed cotton yield/fed. were increased by increasing nitrogen levels. These results are in harmony with those of (Ahmed and Kassem, 2008) and (Sawan et al, 2006).

Data also in Table (7) cleared that $\mathrm{N}$ levels did not exhibit any significant effect on all fiber properties under study in both seasons. In this respect (EIShahawy and Hamoda, 2011) found that hill spacings and nitrogen fertilizer levels and the interaction between them did not exhibit any significant effect on all fiber properties.

3- Effect of the interaction between hill spacing and nitrogen fertilization level:

Data in Table (4) showed that the interaction between hill spacing and nitrogen fertilization levels exerted a significant effect on no. of sympodia/plant and earliness $\%$ but did not exhibit any significant effect on plant height at harvest and first sympodial position in both seasons. The combination between 35 $\mathrm{cm}$ between hills and the level of $75 \mathrm{Kg} \mathrm{N} / \mathrm{fed}$. gave the highest averages of no. of sympodia/plant without any significant differences with $60 \mathrm{Kg} \mathrm{N} / \mathrm{fed}$. These results are in harmony with those of (El-Shahawy and Hamoda, 2011).

Fayoum J. Agric. Res. \& Dev., Vol. 26, No.1, January, 2012 
Abdel-Malak, K.K.; et al.

The interaction between hill spacing and nitrogen fertilization levels had a significant effect in no. of open bolls/plant in the first season only, boll weight in both seasons and seed cotton yield/fed in the second season but did not exhibit any significant effect on lint \%, no. of harvest plants/fed. and seed index (Table 6). The combination between $35 \mathrm{~cm}$ between hills and the level $75 \mathrm{Kg} N / f e d$. gave the highest averages of this traits without any difference with $60 \mathrm{Kg} N / f e d$. These results are in harmony with those of (El-Shahawy and Hamoda, 2011). From these results in general the interaction between 35 hill spacing and $60 \mathrm{Kg} \mathrm{N} / \mathrm{fed}$. were increased yield and yield components.

The interaction between hill spacing and nitrogen fertilization levels did not exhibit any significant effect on all fiber properties in both seasons (Table 8). This may be attributed to the realization that these characteristics are heritable and hence are less affected by the environmental factors. The obtained results are in close agreement with those reported by (Srinivasulu $\boldsymbol{e t}$ al, 2006).

Table 4. Effect of the interaction between hill spacing and nitrogen fertilization levels on growth and earliness traits of the new promising cotton hybrid Giza $90 \times$ Australian during 2010 and 2011 seasons.

\begin{tabular}{|c|c|c|c|c|c|c|c|c|c|}
\hline \multirow{2}{*}{\multicolumn{2}{|c|}{ Treatments }} & \multicolumn{4}{|c|}{ Growth parameters } & \multicolumn{4}{|c|}{ Earliness traits } \\
\hline & & \multicolumn{2}{|c|}{$\begin{array}{c}\text { Plant height } \\
\text { at harvest } \\
(\mathrm{cm})\end{array}$} & \multicolumn{2}{|c|}{$\begin{array}{c}\text { No. of } \\
\text { sympodia/plant }\end{array}$} & \multicolumn{2}{|c|}{$\begin{array}{c}\text { First } \\
\text { sympodial } \\
\text { position }\end{array}$} & \multicolumn{2}{|c|}{$\begin{array}{l}\text { Earliness } \\
(\%)\end{array}$} \\
\hline $\begin{array}{c}\text { Hill } \\
\text { spacing }\end{array}$ & $\begin{array}{c}N \\
\text { fertilization } \\
\text { levels }\end{array}$ & 2010 & 2011 & 2010 & 2011 & 2010 & 2011 & 2010 & 2011 \\
\hline \multirow{4}{*}{$\begin{array}{c}20 \\
\mathrm{~cm} / \mathrm{hills}\end{array}$} & $30 \mathrm{~kg}$ N/fed. & 107.67 & 111.83 & 11.10 & 11.50 & 8.2 & 7.0 & 76.33 & 76.20 \\
\hline & $45 \mathrm{~kg}$ N/fed. & 109.33 & 128.17 & 11.87 & 12.30 & 8.2 & 7.0 & 75.33 & 73.47 \\
\hline & $60 \mathrm{~kg}$ N/fed. & 110.83 & 127.33 & 13.13 & 12.73 & 8.2 & 7.1 & 74.87 & 73.43 \\
\hline & $75 \mathrm{~kg}$ N/fed. & 111.50 & 128.67 & 13.23 & 13.23 & 8.1 & 7.0 & 72.90 & 71.33 \\
\hline \multirow{4}{*}{$\begin{array}{c}25 \\
\mathrm{~cm} / \mathrm{hills}\end{array}$} & $30 \mathrm{~kg}$ N/fed. & 106.67 & 121.00 & 12.17 & 11.73 & 8.0 & 7.0 & 74.70 & 76.80 \\
\hline & $45 \mathrm{~kg}$ N/fed. & 112.33 & 122.50 & 13.37 & 12.57 & 7.9 & 7.0 & 76.60 & 74.40 \\
\hline & $60 \mathrm{~kg}$ N/fed. & 113.17 & 125.50 & 13.80 & 13.20 & 8.2 & 7.1 & 76.00 & 73.90 \\
\hline & $75 \mathrm{~kg}$ N/fed. & 116.67 & 126.50 & 13.87 & 14.10 & 8.1 & 7.0 & 75.27 & 73.10 \\
\hline \multirow{4}{*}{$\begin{array}{c}30 \\
\mathrm{~cm} / \mathrm{hills}\end{array}$} & $30 \mathrm{~kg}$ N/fed. & 109.50 & 114.50 & 12.50 & 14.03 & 8.0 & 7.1 & 78.20 & 75.97 \\
\hline & $45 \mathrm{~kg}$ N/fed. & 107.33 & 115.83 & 13.57 & 14.20 & 7.9 & 7.1 & 78.13 & 75.40 \\
\hline & $60 \mathrm{~kg}$ N/fed. & 111.00 & 117.83 & 14.00 & 14.93 & 7.8 & 7.1 & 78.00 & 73.90 \\
\hline & $75 \mathrm{~kg}$ N/fed. & 111.50 & 123.67 & 14.33 & 15.30 & 8.2 & 7.1 & 75.77 & 71.97 \\
\hline \multirow{4}{*}{$\begin{array}{c}35 \\
\mathrm{~cm} / \mathrm{hills}\end{array}$} & $30 \mathrm{~kg}$ N/fed. & 112.33 & 119.83 & 12.87 & 14.73 & 7.9 & 7.0 & 79.00 & 77.87 \\
\hline & $45 \mathrm{~kg}$ N/fed. & 113.00 & 121.00 & 13.90 & 14.80 & 7.9 & 7.0 & 78.27 & 77.17 \\
\hline & $60 \mathrm{~kg} N / f e d$. & 116.00 & 127.67 & 14.40 & 16.10 & 7.8 & 7.1 & 77.80 & 73.43 \\
\hline & $75 \mathrm{~kg}$ N/fed. & 117.33 & 126.00 & 14.57 & 16.37 & 8.0 & 7.1 & 77.23 & 70.73 \\
\hline & SD & N.S & N.S & 0.35 & 0.49 & N.S & N.S & 1.05 & 0.69 \\
\hline
\end{tabular}

Fayoum J. Agric. Res. \& Dev., Vol. 26, No.1, January, 2012 
Table 5. Effect of hill spacing and nitrogen fertilization levels on yield and yield components of the new promising cotton hybrid Giza $90 \mathrm{x}$ Australian during 2010 and 2011 seasons.

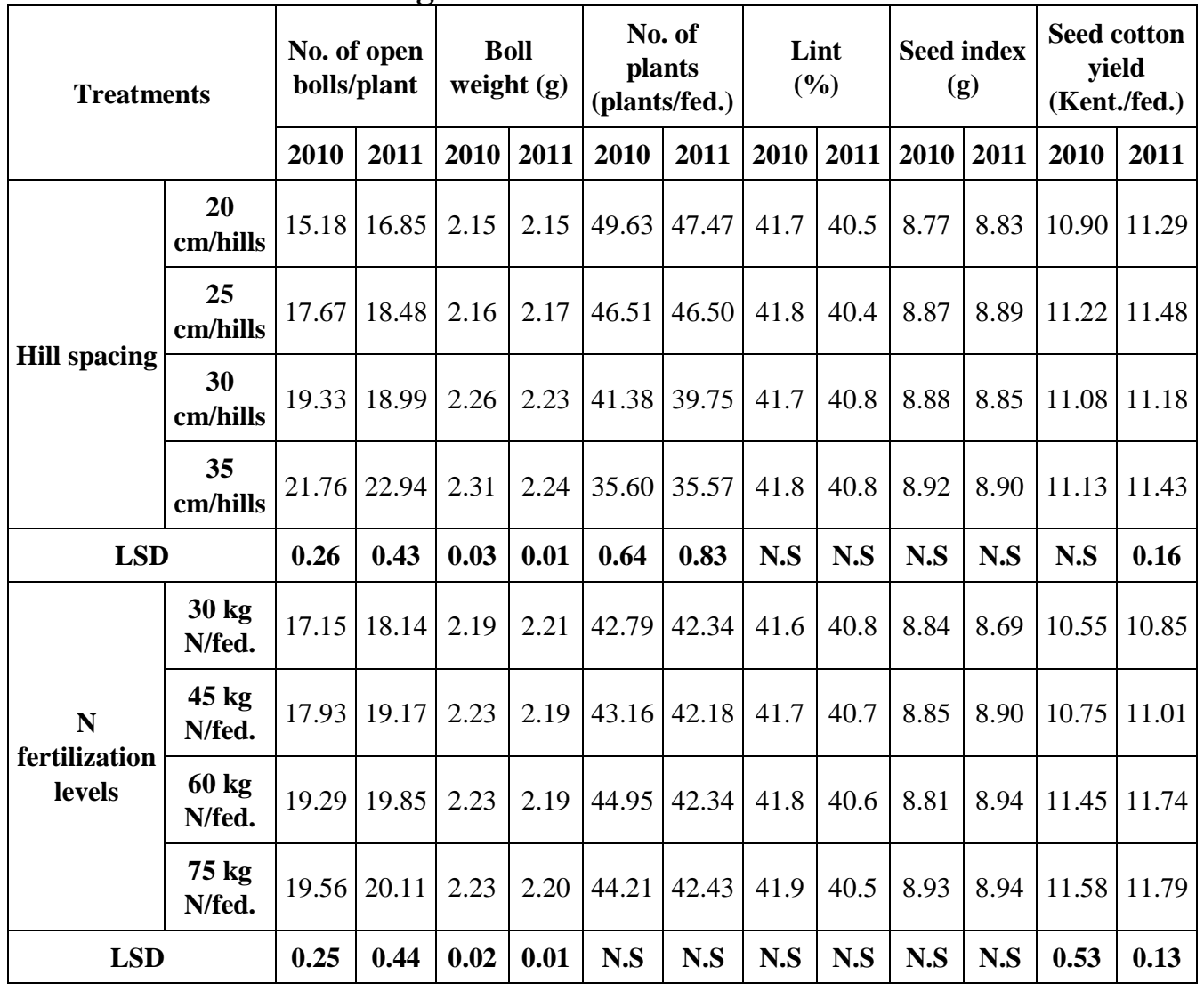

Fayoum J. Agric. Res. \& Dev., Vol. 26, No.1, January, 2012 
Abdel-Malak, K.K.; et al.

Table 6. Effect of the interaction between hill spacing and nitrogen fertilization levels on yield and yield components of the new promising cotton hybrid Giza 90 x Australian during 2010 and 2011 seasons.

\begin{tabular}{|c|c|c|c|c|c|c|c|c|c|c|c|c|c|}
\hline \multicolumn{2}{|c|}{ Treatments } & \multicolumn{2}{|c|}{$\begin{array}{l}\text { No. of open } \\
\text { bolls/plant }\end{array}$} & \multicolumn{2}{|c|}{$\begin{array}{c}\text { Boll } \\
\text { weight }(\mathrm{g})\end{array}$} & \multicolumn{2}{|c|}{$\begin{array}{c}\text { No. of } \\
\text { plants } \\
\text { (plants/fed.) }\end{array}$} & \multicolumn{2}{|c|}{$\begin{array}{l}\text { Lint } \\
(\%)\end{array}$} & \multicolumn{2}{|c|}{$\underset{\text { (g) }}{\text { Seed index }}$} & \multicolumn{2}{|c|}{$\begin{array}{c}\text { Seed cotton } \\
\text { yield } \\
\text { (Kent./fed.) }\end{array}$} \\
\hline $\begin{array}{c}\text { Hill } \\
\text { spacing }\end{array}$ & $\begin{array}{c}\text { Nitrogen } \\
\text { fertilization } \\
\text { levels }\end{array}$ & 2010 & 2011 & 2010 & 2011 & 2010 & 2011 & 2010 & 2011 & 2010 & 2011 & 2010 & 2011 \\
\hline \multirow{4}{*}{$\begin{array}{c}20 \\
\text { cm/hills }\end{array}$} & $\begin{array}{l}30 \mathrm{~kg} \\
\text { N/fed. }\end{array}$ & 14.63 & 15.93 & 2.14 & 2.15 & 49.04 & 47.67 & 41.6 & 40.3 & 8.76 & 8.55 & 10.71 & 10.27 \\
\hline & $\begin{array}{l}45 \mathrm{~kg} \\
\text { N/fed. }\end{array}$ & 14.70 & 16.57 & 2.14 & 2.13 & 50.11 & 47.13 & 41.8 & 40.2 & 8.74 & 8.94 & 10.63 & 11.16 \\
\hline & $\begin{array}{c}60 \mathrm{~kg} \\
\text { N/fed. }\end{array}$ & 15.34 & 17.33 & 2.15 & 2.15 & 49.82 & 47.29 & 41.7 & 41.1 & 8.70 & 8.80 & 10.81 & 11.50 \\
\hline & $\begin{array}{l}75 \mathrm{~kg} \\
\text { N/fed. }\end{array}$ & 16.03 & 17.57 & 2.16 & 2.15 & 49.57 & 47.78 & 41.8 & 40.2 & 8.88 & 9.01 & 11.46 & 12.26 \\
\hline \multirow{4}{*}{$\begin{array}{c}25 \\
\text { cm/hills }\end{array}$} & $\begin{array}{l}30 \mathrm{~kg} \\
\text { N/fed. }\end{array}$ & 15.50 & 17.53 & 2.14 & 2.20 & 46.17 & 46.32 & 41.5 & 40.8 & 8.87 & 8.74 & 10.58 & 11.30 \\
\hline & $\begin{array}{l}45 \mathrm{~kg} \\
\text { N/fed. }\end{array}$ & 16.07 & 18.07 & 2.16 & 2.16 & 46.78 & 46.54 & 41.9 & 40.7 & 8.85 & 8.83 & 10.53 & 11.12 \\
\hline & $\begin{array}{l}60 \mathrm{~kg} \\
\text { N/fed. }\end{array}$ & 19.47 & 19.13 & 2.18 & 2.14 & 46.33 & 46.48 & 41.8 & 40.1 & 8.82 & 8.97 & 12.15 & 11.98 \\
\hline & $\begin{array}{l}75 \mathrm{~kg} \\
\text { N/fed. }\end{array}$ & 19.63 & 19.20 & 2.16 & 2.20 & 46.76 & 46.65 & 42.0 & 40.0 & 8.93 & 9.03 & 11.63 & 11.54 \\
\hline \multirow{4}{*}{$\begin{array}{c}30 \\
\text { cm/hills }\end{array}$} & $\begin{array}{l}30 \mathrm{~kg} \\
\text { N/fed. }\end{array}$ & 17.80 & 17.97 & 2.23 & 2.23 & 40.50 & 39.81 & 41.5 & 41.2 & 8.86 & 8.41 & 10.14 & 11.09 \\
\hline & $\begin{array}{l}45 \mathrm{~kg} \\
\text { N/fed. }\end{array}$ & 19.50 & 18.77 & 2.31 & 2.22 & 40.23 & 39.59 & 41.4 & 40.8 & 8.89 & 8.97 & 11.02 & 10.95 \\
\hline & $\begin{array}{l}60 \mathrm{~kg} \\
\text { N/fed. }\end{array}$ & 19.90 & 19.47 & 2.26 & 2.24 & 40.03 & 39.92 & 41.9 & 40.7 & 8.80 & 8.95 & 11.14 & 11.05 \\
\hline & $\begin{array}{l}75 \mathrm{~kg} \\
\text { N/fed. }\end{array}$ & 20.10 & 19.77 & 2.26 & 2.24 & 40.74 & 39.70 & 42.0 & 40.7 & 8.95 & 9.09 & 12.02 & 11.64 \\
\hline \multirow{4}{*}{$\begin{array}{c}35 \\
\mathrm{~cm} / \mathrm{hills}\end{array}$} & $\begin{array}{c}30 \mathrm{~kg} \\
\text { N/fed. }\end{array}$ & 20.67 & 21.13 & 2.25 & 2.27 & 35.46 & 35.55 & 41.9 & 41.0 & 8.88 & 9.08 & 10.79 & 10.74 \\
\hline & $\begin{array}{l}45 \mathrm{~kg} \\
\text { N/fed. }\end{array}$ & 21.47 & 23.27 & 2.32 & 2.25 & 35.52 & 35.45 & 41.8 & 40.9 & 8.93 & 8.87 & 10.81 & 10.85 \\
\hline & $\begin{array}{l}60 \mathrm{~kg} \\
\text { N/fed. }\end{array}$ & 22.43 & 23.47 & 2.33 & 2.23 & 35.62 & 35.67 & 41.9 & 40.3 & 8.92 & 9.04 & 11.71 & 12.43 \\
\hline & $\begin{array}{l}75 \mathrm{~kg} \\
\text { N/fed. }\end{array}$ & 22.47 & 23.90 & 2.35 & 2.22 & 35.78 & 35.61 & 41.6 & 41.2 & 8.96 & 8.62 & 11.22 & 11.71 \\
\hline \multicolumn{2}{|c|}{ LSD } & 0.49 & N.S & 0.04 & 0.2 & N.S & N.S & N.S & N.S & N.S & N.S & N.S & 0.25 \\
\hline
\end{tabular}

Fayoum J. Agric. Res. \& Dev., Vol. 26, No.1, January, 2012 
EFFECT OF HILL SPACING AND NITROGEN

Table 7. Effect of hill spacing and nitrogen fertilization levels on fiber properties of the new promising cotton hybrid Giza 90 x Australian during 2010 and 2011 seasons.

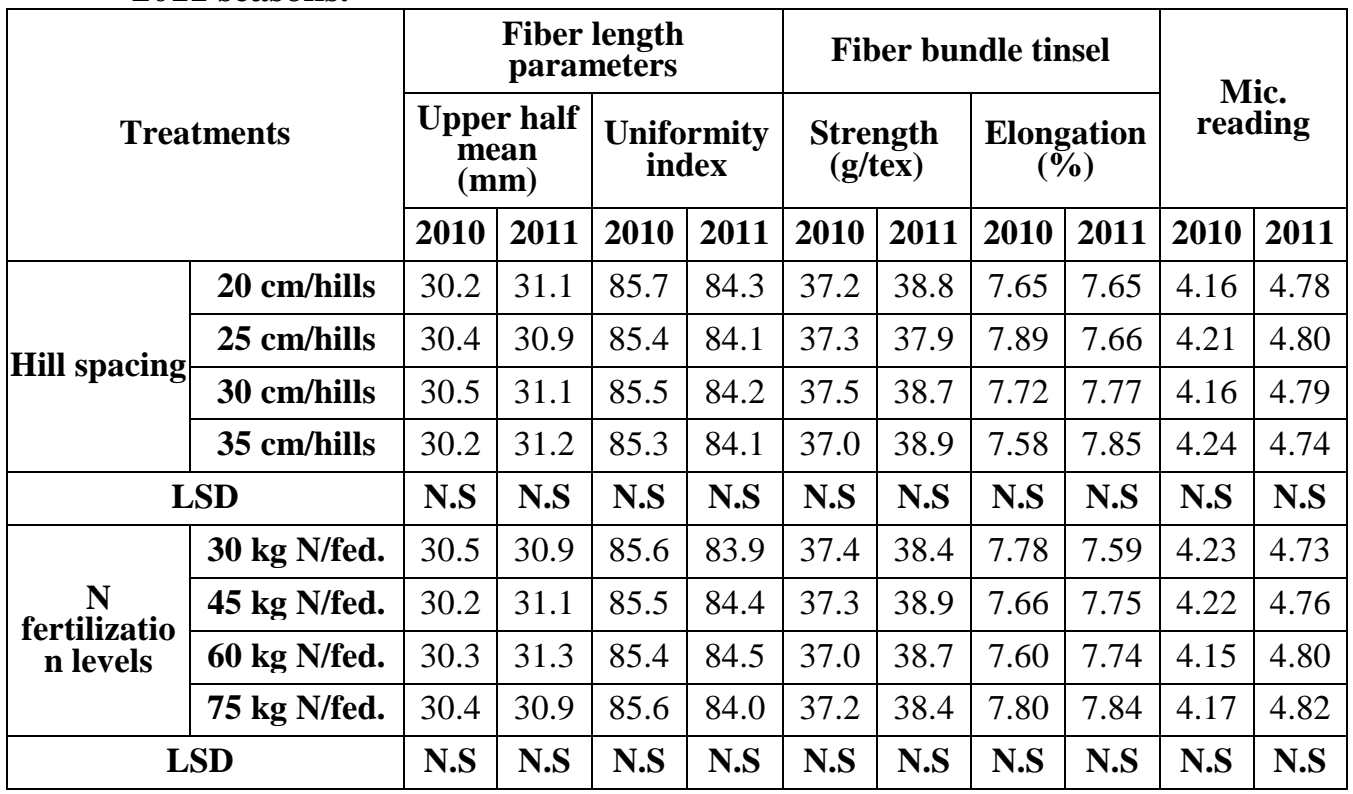

Table 8. Effect of the interaction between hill spacing and nitrogen fertilization levels on fiber properties of the new promising cotton hybrid Giza $90 \times$ Australian during 2010 and 2011 seasons.

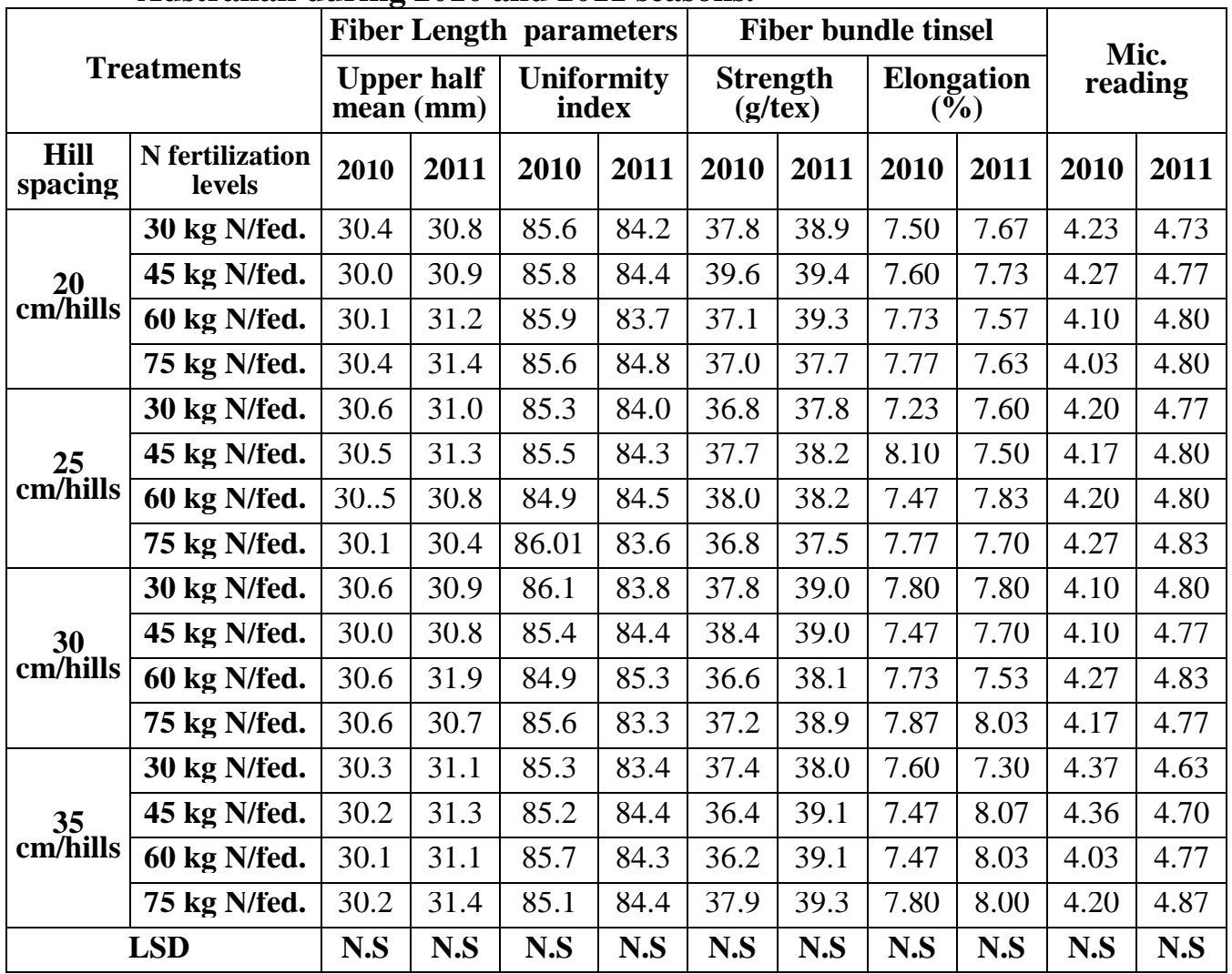

Fayoum J. Agric. Res. \& Dev., Vol. 26, No.1, January, 2012 


\section{REFERENCES}

Abd El-Malik, R.R. and El-Shahawy, M.I. (1999). Impact of plant population density through row and hill spacing under different nitrogen levels on Giza 89 cotton cultivar. Egypt. J. of Agric. Res., 77 (3): 17531767.

A.S.T.M. (1986). American Society for Testing and Materials. D-4605., Vol. 07, No. 1, Easton, MD, USA.

Ahmed, A.M. and Kassem, M.M. (2008). Cotton response to irrigation intervals under different levels of potassium and nitrogen. Assiut J. of Agric. Sci., 39(5): 171-185.

Dong, H.; Wei, J.; Zhen, H.; Wei, T. and Mei, Z. (2005). Evaluation of a production system in China that uses reduced plant densities and retention of vegetation branches. J. of Cotton Sci., 9(1): 1-9.

El-Ganaini, S.S.; Saif El-Yazal, M.A. and Mohamed, S.E. (2005). Botanical studies on cotton (Gossypium vitifolium, L.) plants grown under newly reclaimed soils as affected by nitrogen and phosphorus fertilization. Annals of Agric. Sci., Moshtohor 43(4): 1599-1617.

El-Sayed, E. and El-Menshawi, M. (2005). Response of the promising hybrid cotton Giza 89 × 86 to hill spacing and nitrogen fertilization level. J. Agric. Res. Tanta Univ., 31(3): 436-456.

El-Shahawy, M.I. and Hamoda, S.A. (2011). The proper agricultural management practices four the new promising hybrid cotton (Giza $77 \mathrm{x}$ Pima $S^{6}$ ). J. Plant Production, Mansoura Univ., 2(11):1551-1561.

Eweida, M.H.; Rizk, M.A.; Makram, E.A. and Taleb A.M. (1981). Effect of plant density on growth, yield and some fiber properties of Giza 75 cotton variety. Res. Bulletin, Fac. of Agric., Ain Shams University. No. 1678, 13 pp.; 15 ref.

Gomez, K.A. and Gomez, A.A. (1984). Statistical procedures for agriculture research. $2^{\text {nd }}$ Ed., John Willey and Sons, New York, USA.

Hamed, F.S. (2006). Response of cotton cultivar Giza 90 to population density and nitrogen levels. Assuit J. of Agric. Sci., 37(3): 173-184.

Hamoda, S.A. (2010). Impact of water stress and nitrogen fertilization levels on cotton grown under high temperature conditions in Upper Egypt. Minufiya J. Agric. Res., 35(5): 1797-1814.

Ibrahim, M.A. (2008). Effect of irrigation intervals under different NPK rates on the yield and its components on cotton. Ph. D. Thesis, Fac. of Agric., Al-Azhar Univ., Egypt.

Khan, K.; Mahmood, Z.; Soomro, A. and Ilyas, M. (2005). Effect of different levels of nitrogen on cotton yield and its components under climatic condition of D. I. Khan. Indus Cottons. 2(3): 241-244.

Obasi, M.O. and Msaakpa, T.S. (2005). Influence of topping, side branch pruning and hill spacing on growth and development of cotton (Gossypium barbadense, L.) in the Southern Guinea Savanna location of Nigeria. J. of Agric. and Rural Development in the Tropics and Subtropics, 106(2): 155-165.

Sawan, Z.M.; Mahmoud, M.H. and El-Guibali, A.H. (2006). Response of yield, yield components and fiber properties of Egyptian cotton (Gossypium barbadense, L.) to nitrogen fertilization and foliar-applied potassium and mepiquat chloride. J. Cotton Sci.; 10(4): 224-234.

Fayoum J. Agric. Res. \& Dev., Vol. 26, No.1, January, 2012 
Srinivasulu, K.; Hema, K.; Prasad, N. and Rao, K. (2006). Performance of cotton hybrids under different spacings and nitrogen levels in black cotton soils of costal Andhra Pradesh. J. of Cotton Res. \& Development. 20(1): 99-101.

\section{تأثير المسافة بين الجور ومستوي التسميل النتروجيني علي هجين القطن المبشر}

كرم كامل أسرائيل عبد الملاك، مصطفي عطية احمد عمارة وسعيد عبد التواب فرج حمودة

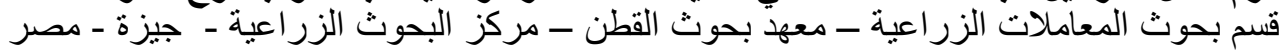

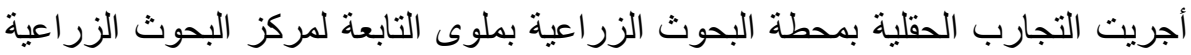

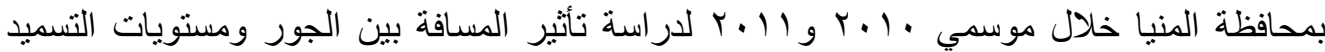

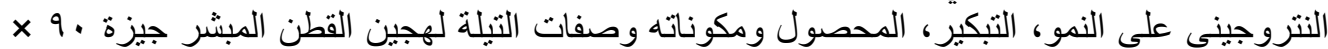

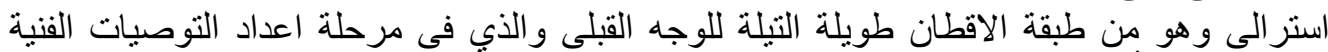

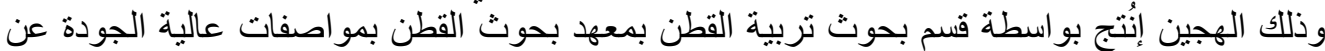
الاصناف التجارية المنزر عة فئ.

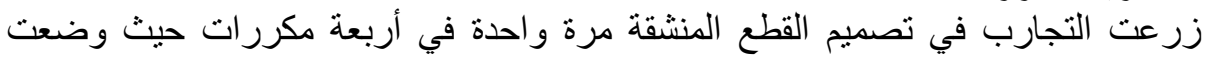

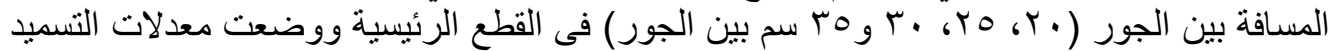

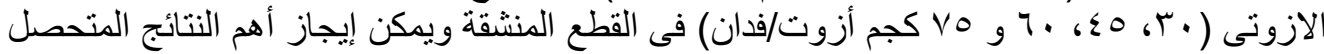

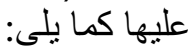

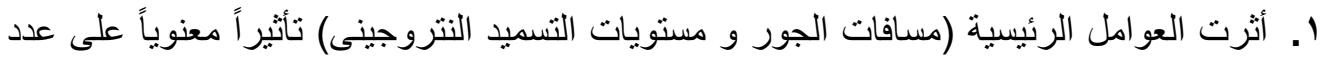

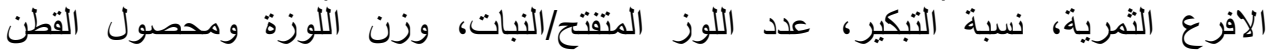

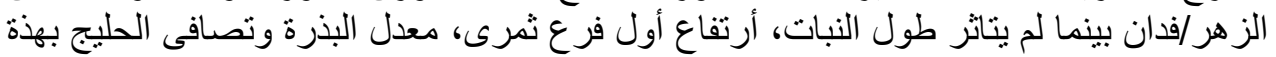

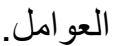

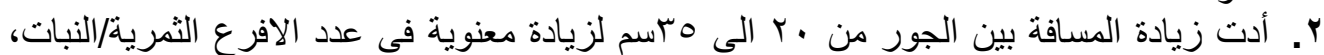

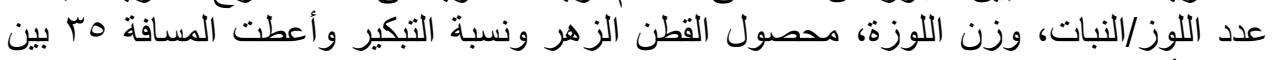

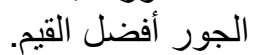

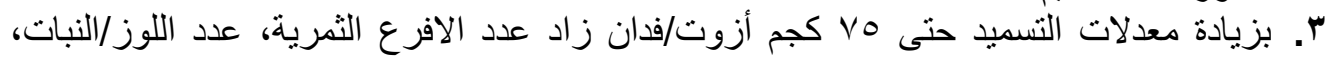

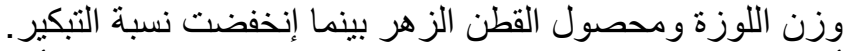

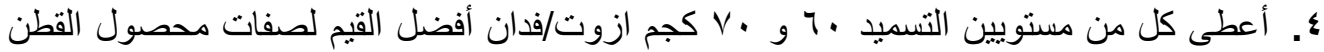

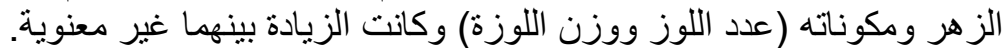

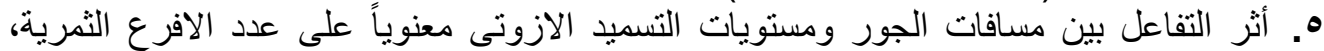

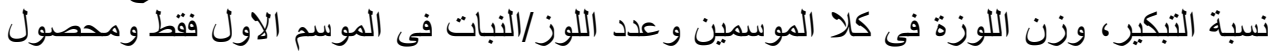

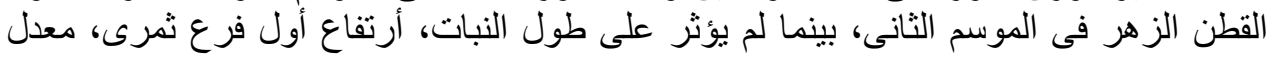
البذرة وتصافى الحليج.

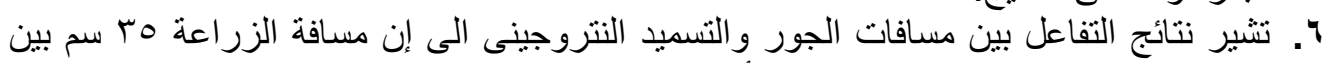

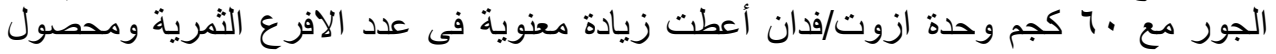

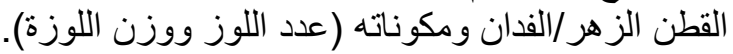

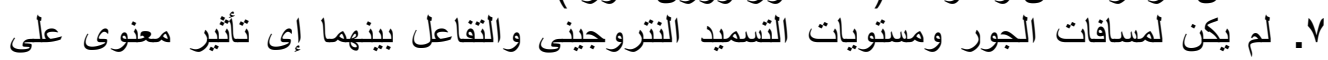

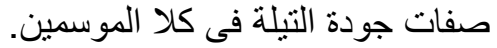

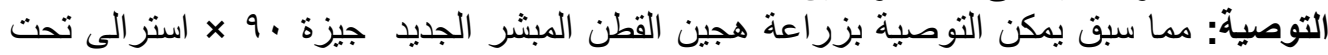

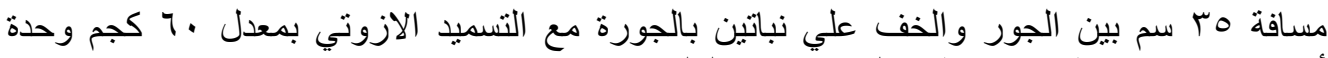
أزوت/فدان تحت ظروف منطقة ملوى بمصر العليا.

Fayoum J. Agric. Res. \& Dev., Vol. 26, No.1, January, 2012 